\title{
Examining the Process Behind the Decision of Sports Fans to Attend Sports Matches at Stadiums Amid the SARS-CoV-2 Pandemic: The Case of South Korea
}

\author{
Yunduk Jeong ${ }^{1}$, Suk-Kyu Kim ${ }^{2}$ aD and Jae-Gu Yu ${ }^{3, *(D)}$ \\ 1 College of General Education, Kookmin University, Seoul 02707, Korea; jeongyunduk@kookmin.ac.kr \\ 2 Department of Sports Science, Dongguk University, Gyeongju 38066, Korea; skkim2018@dongguk.ac.kr \\ 3 Department of Sport Industry, Chungang University, Anseong 17546, Korea \\ * Correspondence: unlisted@cau.ac.kr
}

Citation: Jeong, Y.; Kim, S.-K.; Yu, J.-G. Examining the Process Behind the Decision of Sports Fans to Attend Sports Matches at Stadiums Amid the SARS-CoV-2 Pandemic: The Case of South Korea. Sustainability 2021, 13, 3403. https://doi.org/10.3390/ su13063403

Academic Editor: Jonathan M. Casper

Received: 17 February 2021

Accepted: 16 March 2021

Published: 19 March 2021

Publisher's Note: MDPI stays neutral with regard to jurisdictional claims in published maps and institutional affiliations.

Copyright: (c) 2021 by the authors. Licensee MDPI, Basel, Switzerland. This article is an open access article distributed under the terms and conditions of the Creative Commons Attribution (CC BY) license (https:/ / creativecommons.org/licenses/by/ $4.0 /)$.

\begin{abstract}
The spread of SARS-CoV-2 has taken a toll on the sports industry worldwide. One of the key challenges for team managers or marketers is to understand how it affects the decisionmaking process of sports fans. This study examined the process behind the decision of sports fans to attend sports matches at stadiums amid the pandemic using the theory of planned behavior (TPB), which includes the moderating roles of team identification. Responses were obtained from 269 undergraduate and graduate students who had attended a sports match in 2019. Structural equation modeling was performed to evaluate three factors: the attitude toward attending sports matches, subjective norm, and perceived behavioral control on the decision to attend. In addition, a hierarchical regression analysis was conducted to test the moderating effects of team identification. The findings displayed the positive influences on attendance intention from the perspective of (a) attitude, (b) subjective norm and (c) perceived behavioral control. On the other hand, team identification did not have a moderating effect on the relationships among attitude, subjective norm and perceived behavioral control regarding the intention to attend a sport event. These findings suggest that it is important to grasp the role of volitional and non-volitional processes to explain the how the decision to attend sports matches is made.
\end{abstract}

Keywords: SARS-CoV-2; the Theory of Planned Behavior; sport event attendance intention; professional sports league; South Korea

\section{Introduction}

The SARS-CoV-2 pandemic, which was first reported in Wuhan in December 2019, has spread to more than 190 countries and regions outside mainland China [1]. It has now infected more than 110 million people worldwide [2], and the number of people infected in the U.S. surpassed 28 million as of 8 March 2021 [3]. Governments worldwide have placed their countries on lockdown to curb the spread of SARS-CoV-2. People worldwide are practicing social distancing, and masks have become necessary in South Korea [4]. Today, South Korea is on high. Alert, and fear of the virus has resulted in several unrelated parts of life shutting down completely [5]. Many students cannot return to school, so classes are being taught online [6].

The spread of SARS-CoV-2 has taken a toll on various industries. Tourism, one of the fastest growing economic sectors globally, has taken a critical hit and quickly become one of the worst affected [7]. The drop in travel has negatively affected tourism, and quarantines and work closures have brought the global supply chain to a halt. In addition to the tourism sector, as the pandemic continues to worsen, the sports industry has struggled for survival [8]. Many major sporting events, such as the Tokyo 2020 Summer Olympics, 2020 World Team Table Tennis Championships Busan, and Asian Football Confederation (AFC) Champions League, have been postponed. Moreover, physical training facilities, 
such as fitness centers, Taekwondo gymnasiums, and indoor golf driving ranges, have been shut down in South Korea. The government has imposed stricter social-distancing rules to address the resurgence of SARS-CoV-2.

Major South Korean professional sports leagues (e.g., baseball, soccer, basketball, and volleyball) were held without spectators or allowed to have up to 30 percent of the seating capacity during the 2020 season [9]. Operating without spectators or reduced capacity has resulted in a steep revenue decline for professional sports teams. Moreover, there is a fear that sports fans might become accustomed to other entertainment options during these months without sports [10]. If sports fans become increasingly disinterested in professional sports due to the pandemic, the league, which is considered the core of the sports industry, is likely to confront a financial crisis. This means that the industry may be in danger of collapse in the near future. Given this emerging phenomenon, it is crucial to understand the decision-making process of sports fans for attending sports matches amid the SARS-CoV-2 pandemic.

To understand such decision formation and behavior better, the current study approached the theory of planned behavior (TPB) [11,12], an extension of the theory of reasoned action (TRA) [13], and has been one of the important consumer behavior formation models in various fields over the last several decades. Likewise, sports management literature has paid strong attention to this theory to predict a sports consumers' decision formation and behavior [14-18]. In addition, the present study examined the moderating impacts of team identification, which is considered to be an important predictor of the consumption behavior of various sports [19]. If team identification can moderate the paths among research variables, then sports teams can market themselves to fans, and segment them according to the level of team identification using different strategies. For a group with high team identification, marketers may be required to concentrate on quarantine measures at a team's home stadium, but for a group with a low team identification the focus might be on building team identification and further publicizing the safety of the team's home stadium to increase attendance. Because most team marketing managers cannot invest a lot of money, time, or energy into attracting fans, focusing on low team identification groups may be a cost-effective means of attracting fans.

Accordingly, this study developed a model to indicate the sports fans' decision-making process for attending sports matches at stadiums amid the SARS-CoV-2 pandemic using the TPB framework (attitude, subjective norm, and perceived behavioral control). Furthermore, this study examined the moderating impacts of team identification, which will fill gaps in the existing literature. Previous studies on sports management focused primarily on the direct effects of the independent TPB variables on sport event attendance intention with little emphasis on moderating factors, particularly team identification [16], which could improve understanding of professional sports marketing. The validities and reliabilities of the involved measures were investigated by conducting confirmatory factors, Cronbach's alpha, and correlation analyses. A modeling analysis using a structural equation was conducted to examine the relationships among the research variables, and a hierarchical regression analysis was carried out to test the moderating effects of team identification.

\section{Literature Review, Research Hypotheses, and Model}

\subsection{Information on South Korean Professional Sports}

In South Korea, professional sports were launched to distract people from becoming involved with, or paying attention to, politics as part of the so-called "3S (sports, screen, and sex) policy" led by the military government in the early 1980s. Faced with pressure from government, major Korean corporations developed professional sports teams and participated in leagues as a marketing tool for public relations. Consequently, six professional baseball teams were founded in 1982, and five soccer teams were launched in 1983 [20]. With the establishment of professional basketball in 1997 and volleyball leagues in 2004, attending or watching professional sports has become one of the most favored leisure activities [21]. Professional sports leagues in Korea have been growing for more than 
30 years as the industry fulfilled the needs of the public [22]. The association for each professional sports leagues actively adjusted and revised its rules to improve the fun and rapid flow of the game. For example, baseball, soccer, and volleyball introduced a video assistant referee system (VARS) to ensure accurate judgment. As of 2021, 10 professional associations have been organized in seven sports: baseball, soccer, basketball, volleyball, golf, boxing, and go. Among these, four leagues are actively progressing: baseball, soccer, basketball, and volleyball.

\subsection{The Theory of Reasoned Action (TRA) and Theory of Planned Behavior (TPB)}

Amidst the many theories of behavioral change, the theory of reasoned action (TRA) [13] and the theory of planned behavior (TPB) [11,12] have been the most popular socialpsychological approaches to understanding human behavior. The key of the two theories is an individual's intention to perform a certain behavior, which points to the willingness or readiness to engage in it [23]. According to the TRA, a specific human behavior is determined by an intention that reflects two main attributes: attitude toward the behavior and the subjective norm, which is under complete volitional control $[23,24]$. In other words, the theory posits that an individual would rather make a conscious personal choice than follow external forces during the decision-making process [25].

According to Fishbein and Ajzen [26] (p. 76), attitude is viewed as "a latent disposition or tendency to respond with some degree of favorableness or unfavorableness to a psychological object." Similarly, Kim, Lee and Yoon [27] (p. 323) reported that the concept is represented as "the overall evaluations of the performance of a behavior in question." Moreover, Fishbein and Ajzen [26] recognized that attitude towards a behavior could be predicted by behavioral beliefs with respect to the expected outcomes of performing the behavior. Therefore, a positive attitude toward a behavior is linked with the personal belief that performing it has desirable consequences [28]. In the TRA model, another volitional determinant of behavioral intention is the subjective norm, as already mentioned. The term is defined as "perceived social pressure to engage in the behavior" [29] (p. 1818) and is predicted by one's normative beliefs that important referent individuals (e.g., family, friends, relatives, colleagues, supervisors, or business partners) think that the person should or should not perform the behavior [30]. In other words, the perceived social pressure is predicted by both normative beliefs and motivation to meet the expectations of the referents. A sports fan is more likely to attend a game at a stadium during the pandemic if an important referent approves.

On the other hand, if a person loses a job due to the SARS-CoV-2 outbreak and then has a very difficult time finding a new one, the person can be prevented from attending a sports game or paying for a TV license fee for the game because of a lack of money. As a result, many researchers have recognized that the assumption of complete volitional control has some limitations on the applicability of the TRA to anticipate a diversity of human behavior in various fields [31]. For this reason, the researchers highlighted the necessity of a broadened version of the TRA. Ajzen [23] developed the theory of planned behavior (TPB) that incorporates an additional construct, perceived behavioral control (PBC), which is defined as "people's perceptions of their ability to perform a given behavior." [31] (p. 316); that is, PBC should be the highest when individuals have sufficient resources, time, and opportunities to overcome the difficulties of execution [32]. Overall, the commonality between the TRA and TPB addresses the impacts of cognitive components like attitude and the subjective norm on the intention to perform a behavior. On the other hand, the major difference between the TRA and TPB is that while the TRA solely includes volitional factors (attitude and subjective norm), the TPB considers both volitional and non-volitional (PBC) dimensions [33]. PBC was included to deal with situations in which individuals may lack complete volitional control over their intended behavior [31]. For example, if undergraduate or graduate students cannot have part-time employment because of SARS-CoV-2, they are likely to have difficulty attending sports matches because of a lack of money. 


\subsection{Research Hypotheses Development}

Consistent with the TPB, this study hypothesized that attitude is an antecedent of the intention to attend a sports match. Many studies support the attitude-behavior intention link. For example, Guo, Berkshire, Fulton, and Hermanson [34] investigated what influences the behavior of U.S. healthcare administrators in the context of healthcare management and revealed that attitude was the strongest predictor in their intention to use evidence-based management. Lee, Won, and Bang [35] examined the relationships among attitude, subjective norm, $\mathrm{PBC}$, intention to return to volunteering, and actual return to an annual sport event and demonstrated that attitude was a predictor of the intention to return to volunteering. In addition, Eddosary, Ko, Sagas, and Kim [15] explored the intention of consumers to attend soccer events using an extension of TPB and found that attitude was significantly related to students' intention to attend. Therefore, this paper proposes the following hypothesis:

Hypothesis 1 (H1): Attitude will positively influence sport event attendance intention.

Mixed evidence exists on the relationship between the subjective norm and behavioral intention [36]. For example, by examining the structural relationships between festival quality, attitude, subjective norm, PBC, and behavioral intention, Vesci and Botti [37] confirmed that the subjective norm played a key role in forming a behavioral intention. Reysen, Chadborn, and Plante [38] explored the variables predicting the fans' intention to attend a fan-related convention and reported that the subjective norm acted as an antecedent of intention to a fan-related convention. Cunningham and Kwon [39] explored antecedents of intention to attend a hockey event using the TPB framework. They reported that the subjective norm was a critical determinant of the intentions. Based on empirical perspectives described in the literature, the following is postulated:

Hypothesis 2 (H2): Subjective norm will positively influence sport event attendance intention.

There is increasing awareness that PBC leads to a behavioral intention. Chiu, Bae, and Won [40] investigated the viewing intention in the context of Major League Baseball using the TPB as a theoretical framework and indicated that PBC positively predicted the viewing intention. Lee [41] examined the association of personal, social, and environmental variables with leisure-time walking, confirming that PBC results in higher levels of intention. Similarly, Zhang and Cha [42] applied a TPB model to analyze the relationship among attitude, subjective norm, $\mathrm{PBC}$, and viewing intention of e-sports competitions in China and emphasized that PBC improved the intention. Based on the above discussions, the following hypothesis is formulated:

Hypothesis 3 (H3): Perceived behavior control will positively influence sport event attendance intention.

Regarding the moderating role of team identification, as discussed above, attitude, subjective norm, and PBC are likely to build behavioral intention [37-42]. Concerning the relation between team identification and behavioral intention, Suh, Ahn, and Pedersen [43] tested the effects of team identification, e-service quality, and satisfaction on the intention to revisit sports websites, and demonstrated that team identification boosted the revisitation. In other words, all the independent variables are likely to boost the behavioral intention. On the other hand, there is no sufficient evidence for positive relationships between attitude and team identification, subjective norm and team identification, or PBC and team identification. Moreover, there has been considerable discussion about studying the moderating role of team identification in the context of sports marketing literature. For example, Theodorakis, Koustelios, Robinson, and Barlas [44] analyzed the moderating role of team identification on the relationship between service quality and repurchase 
intentions among spectators of professional sports. They suggested that team identification moderated the relationship between service quality and repurchase intentions. Recently, Lee, Gipson, and Barnhill [45] reported that team identification had a moderating effect in their proposed model. Accordingly, the present study proposed the following hypotheses:

Hypothesis 4 (H4): Team identification will have a moderating effect on the relationship between attitude and sport event attendance intention.

Hypothesis $\mathbf{5}$ (H5): Team identification will have a moderating effect on the relationship between subjective norm and sport event attendance intention.

Hypothesis 6 (H6): Team identification will have a moderating effect on the relationship between perceived behavior control and sport event attendance intention.

Based on a thorough review of previous studies, the current study proposed the following conceptual model (Figure 1).

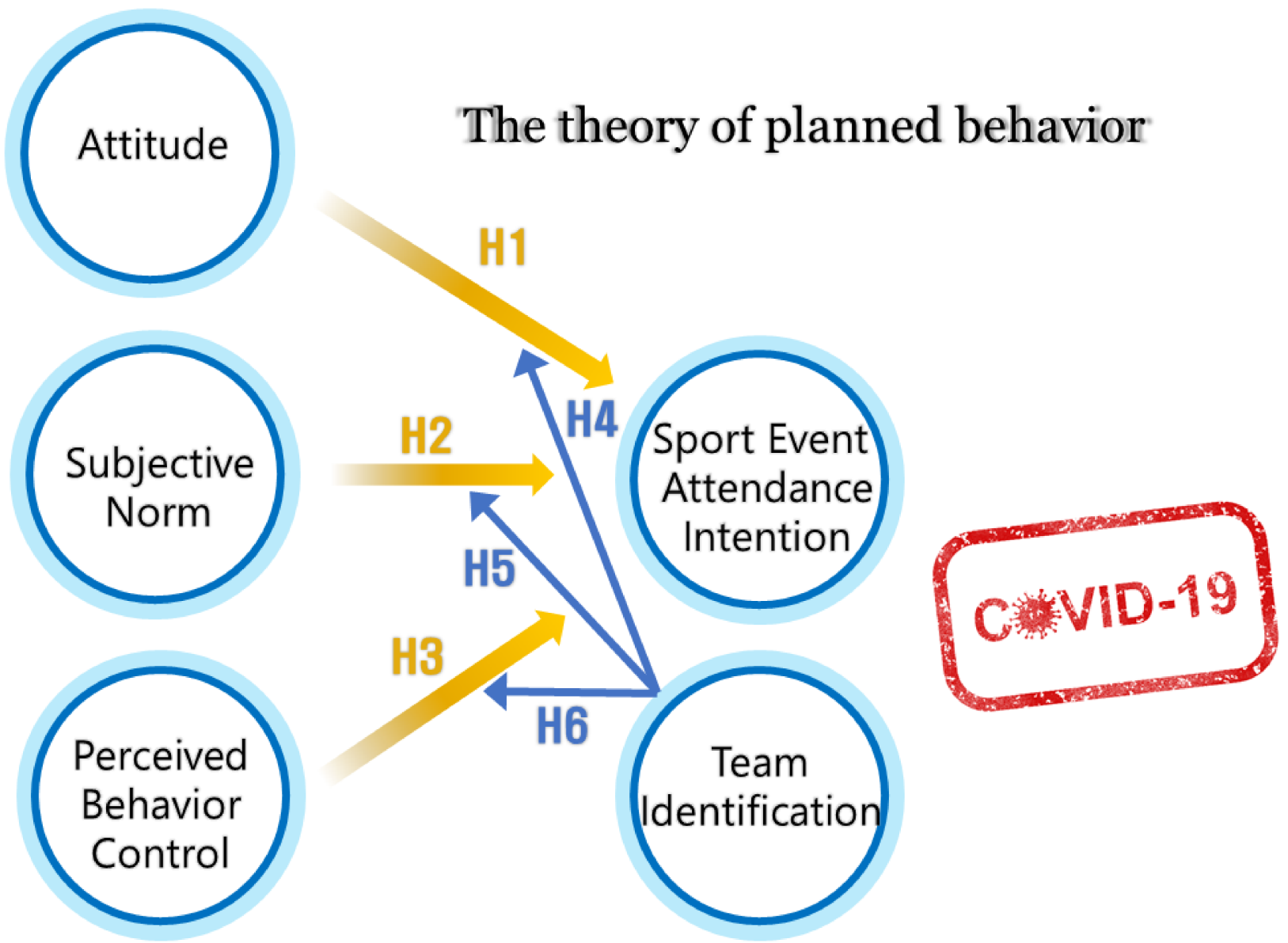

Figure 1. Proposed conceptual model.

\section{Method}

\subsection{Data Collection}

The present study used a convenience sampling approach. The survey was distributed to undergraduate and graduate students attending one of three colleges in South Korea and had attended a sports match in 2019. The reason that college students were approached is that people in their twenties account for approximately $50 \%$ of the total spectators of a professional sports match in South Korea [46], which means that they play an important 
part in the professional sports industry. The authors and two trained research assistants administered non-face-to-face questionnaires using a Google survey from October 12 to 16, 2020. We contacted three professors we were acquainted with and then received the e-mail addresses of their students under their mutual consent. A total of 330 students were approached and asked politely to participate in the survey without reward. In all, 282 respondents completed it, giving a survey response rate of $85.5 \%$. Thirteen students were subsequently removed due to excessive missing data; overall, 269 usable survey questionnaires were gathered. These respondents were split almost equally according to sex (males 68\%, $n=183$; females 32\%,n=86) and education level (undergraduate students $69.9 \%, n=188$; graduate students $30.1 \%, n=81$ ). Most of the respondents earned an annual household income between US\$30,000 and US\$49,999 $(21.2 \%, n=57)$.

\subsection{Measures}

This study addressed the theoretical relationships among attitudes, subjective norm, PBC, and sport event attendance intention and the moderating role of team identification. The survey instrument was modified and adapted using scales from previous studies. The questionnaire consisted of six main sections: (a) attitude, (b) subjective norm, (c) PBC, (d) sport event attendance intention, (e) team identification, and (f) demographic information. Attitude was assessed using four items derived from those used by Kim et al. [28], Han et al. [33], and Han, Hsu, and Sheu [47]: positive-negative, good-bad, favorable-unfavorable, and worthless-valuable, with an interval scale ranging from 1 to 7. The subjective norm was measured by three items adopted by Kim et al. [28] and Ajzen [48]. The PBC was derived from Ajzen [23], Han et al. [33], and Perugini and Bagozzi [49]. Regarding the sport event attendance intention, three items were derived from Shapiro, Ream, and So [50]. The format for the 19-item survey instrument was a seven-point Likert scale, ranging from 1 (strongly disagree) to 7 (strongly agree). To ensure content validity, a panel of four sport management professors was invited to clarify these items. Based on their feedback, the preliminary questionnaire was modified and improved for final adoption and distribution.

\subsection{Data Analysis}

Data collected using the questionnaire were analyzed using SPSS 22.0 and AMOS 22.0 software packages. SPSS was used for frequency analysis, reliability analysis, correlation analysis, and hierarchical regression analysis on the moderating effects of team identification. AMOS was used to perform confirmatory factor analysis and structural equation modeling.

\subsection{Validity and Reliability}

To examine the normality assumption, the present study verified skewness and kurtosis values for the scale items. According to the guidelines of severe non-normality, skewness should be within the range \pm 2 and kurtosis should be within the range \pm 7 . As all skewness values were within the range \pm 2 and all kurtosis values were within the range \pm 7 , the normality assumption of all the scale items was well met.

The current study used confirmatory factor analysis (CFA) to confirm the dimensionality of the measurement model using the maximum likelihood estimation via AMOS version 22.0 .

The goodness-of-fit indices of CFA displayed a satisfactory fit with the data $\left(x^{2} / d f=1.513, \mathrm{NFI}=0.959, \mathrm{RFI}=0.941, \mathrm{IFI}=0.986, \mathrm{TLI}=0.979, \mathrm{CFI}=0.986\right.$, and RMSEA $=0.044)($ Table 1$)$, all of which were within the recommended thresholds [51]. To evaluate the convergent validity, the present study calculated the factor loadings, construct reliability (CR), and average variance extracted (AVE) based on the measurement model. As shown in Table 1, all factor loading values (0.677-0.942) were statistically significant $(p<0.001)$ and greater than the cutoff value of 0.5 [52]. All CR values (0.759-0.873) exceeded the minimum requirement of 0.7 , and all AVE values $(0.513-0.662)$ were above the 
minimum of 0.5 [53] (Table 1). Therefore, convergent validity was satisfactory. To confirm the discriminant validity, the current study verified that the AVE of the latent variable was greater than the square of the correlation coefficient between the latent variables. Because it is not easy to verify all variables, the pair with the highest correlation coefficient was selected and verified. The highest correlation coefficient was 0.659 (subjective norm-sport event attendance intention) (Table 2), and the square of 0.659 was 0.434 . The AVE of the subjective norm was 0.541 , and that of sport event attendance intention was 0.542 . Because the AVE values were all greater than the square of the highest correlation coefficient ( 0.541 and $0.542>0.434$ ), the discriminant validity was satisfactory. Reliability estimates (Cronbach's alpha) for attitude, subjective norm, PBC, team identification, and sport event attendance intention (0.800-0.915) were above the recommended threshold of 0.7 , suggesting that the measures were reliable [53] (Table 1).

Table 1. Summarized results for the validity and reliability assessments.

\begin{tabular}{|c|c|c|c|c|}
\hline Scale Items & $\begin{array}{c}\text { Standardized } \\
\text { Loadings }\end{array}$ & CR & AVE & Cronbach's $\alpha$ \\
\hline & Attitude & \multirow{6}{*}{0.873} & \multirow{6}{*}{0.633} & \multirow{6}{*}{0.852} \\
\hline $\begin{array}{c}\text { For me, to attend a sports match at a stadium durir } \\
\text { the spread of SARS-CoV-2 is }\end{array}$ & & & & \\
\hline Extremely negative ... Extremely positive & 0.958 & & & \\
\hline Extremely bad ... Extremely good & 0.918 & & & \\
\hline Extremely unfavorable ... Extremely favorable & 0.900 & & & \\
\hline Extremely worthless ... Extremely valuable & 0.776 & & & \\
\hline
\end{tabular}

People important to me (e.g., family/friends) would approve of me attending a sports match when the

stadium is open to spectators.
People important to me (e.g., family/friends) think

Subjective Norm

that I should attend a sports match when the stadium is open to spectators.

0.806

0.778

0.541

0.841

0.904

People close to me (e.g., family/friends) are likely to watch a sports match when the stadium is open to spectators

0.708

\section{Perceived Behavioral Control}

Whether or not I attend a sports match at a stadium is completely up to me when the stadium is open to spectators 0.901

I am confident that if I want, I can attend a sports match at a stadium when the stadium is open to spectators

I have enough resources, time, and opportunities to attend a sports match at a stadium.

\section{Team Identification}

When someone criticizes [athletic team], it feels like a personal insult.

When the [athletic team] loses a game, it feels like a personal failure.

0.677

0.829

0.759

0.513

0.800

I feel a sense of ownership for [athletic team] rather than being just a fan of the team.

0.775

\section{Sport Event Attendance Intention}

I would attend a sports match when the stadium is open to spectators.

I would consider attending a sports match when the stadium is open to spectators.

0.884

0.780

0.542

0.915

The probability that I would consider attending a sports match is high when the stadium is open to spectators. 
Table 2. Correlations between the constructs.

\begin{tabular}{cccccc}
\hline & AT & SN & PBC & TI & SEAI \\
\hline AT & 1 & & & & \\
SN & $0.560^{* *}$ & 1 & & & \\
PBC & $0.296^{* *}$ & $0.353^{* *}$ & 1 & 1 & \\
TI & $0.278^{* *}$ & $0.484^{* *}$ & $0.338^{* *}$ & $0.313^{* *}$ & 1 \\
SEAI & $0.554^{* *}$ & $0.659^{* *}$ & $0.501^{* *}$ & 0.70 .
\end{tabular}

${ }^{* *} p<0.01$, AT: attitude, SN: subjective norm, PBC: perceived behavioral control, TI: team identification, and SEAI sport event attendance intention.

\section{Results}

\subsection{Model Fit and Structural Model}

Structural equation modeling (SEM) was carried out to test hypothesized relationships. All goodness-of-fit indices of the structural model showed that the model achieved an acceptable fit $\left(\mathrm{x}^{2} / d f=1.515, \mathrm{GFI}=0.953\right.$, AGFI $=0.927, \mathrm{NFI}=0.971, \mathrm{RFI}=0.962$, and RMSEA $=0.044)$ [54]. Hypotheses 1, 2, and 3 were tested. As shown in Figure 2, the relationship between the attitude and sport event attendance intention (Hypothesis 1) was established $(0.169, p<0.01)$. The subjective norm had a significant positive effect on the sport event attendance intention $(0.513, p<0.001)$, which supports Hypothesis 2 . The path coefficient from $\mathrm{PBC}$ to sport event attendance intention was positive and statistically significant $(0.310, p<0.001)$, supporting Hypothesis 3.

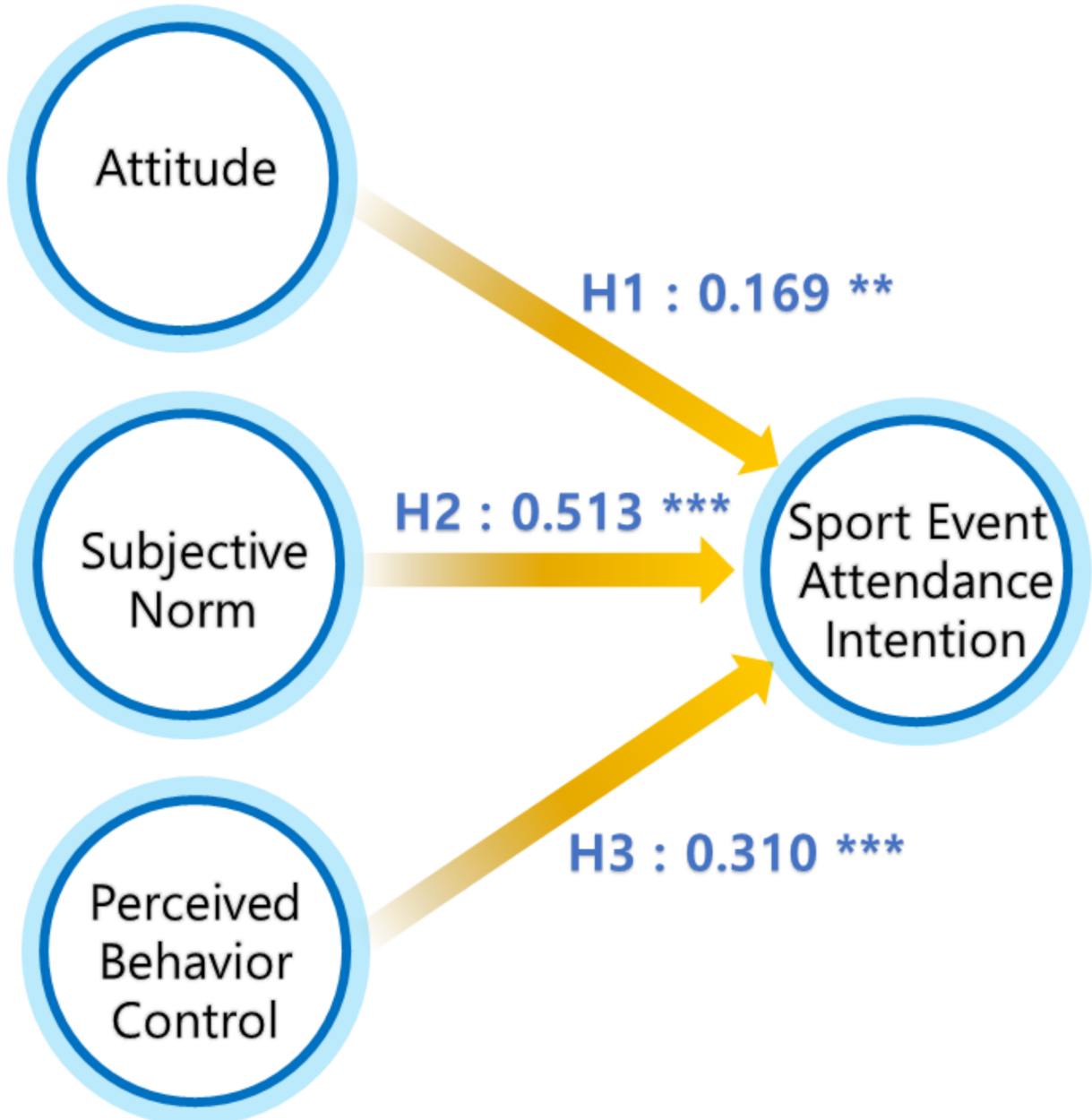

Figure 2. Results of structural model. Note. ${ }^{* *} p<0.01,{ }^{* * *} p<0.001$. 


\subsection{Moderating Effect of Team Identification}

The present study used hierarchical regression analysis to identify the moderating effects of team identification. As shown in Table 3, in Model 1, a significant regression equation was found $(\mathrm{F}=108.943, p<0.001)$, with an $R^{2}$ of 0.547 , and attitude ( $\beta=0.228, t=4.562, p<0.001)$, subjective norm $(\beta=0.433, t=8.473, p<0.001)$, and PBC $(\beta=0.281, t=6.340, p<0.001)$ had significant impacts on the sport event attendance intention. In Model 2, the regression equation was found to be significant $(F=82.776$, $p<0.001$ ) with an $R^{2}$ of 0.550 . On the other hand, when "team identification" was entered into the model, the variable was not significant. Finally, in Model 3, the regression equation was significant $(\mathrm{F}=47.262, p<0.001)$, with an $R^{2}$ of 0.547 , and the Durbin-Watson statistic had 2.012 value, indicating no autocorrelation. When three interaction variables (e.g., attitude $\times$ team identification, subjective norm $\times$ team identification, and $\mathrm{PBC} \times$ team identification) were entered into the model, the variables were not significant predictors for the dependent variable: the sport event attendance intention. Therefore, team identification did not have a moderating effect on the relationships between attitude and sport event attendance intention, subjective norm and sport event attendance intention, or PBC and sport event attendance intention, thus disproving Hypotheses 4, 5, and 6.

Table 3. Moderating effects of team identification.

\begin{tabular}{|c|c|c|c|c|c|c|}
\hline Model & Variable & $\begin{array}{c}\text { Standardized } \\
\text { Coefficients }\end{array}$ & Std. Error & $\mathbf{t}$ & $\mathbf{F}$ & $\begin{array}{c}\mathrm{R}^{2} \\
\left(\text { Adjusted } \mathrm{R}^{2} \text { ) }\right.\end{array}$ \\
\hline \multirow{4}{*}{1} & (Constant) & & 0.066 & $47.771^{* * *}$ & \multirow{4}{*}{$108.943^{* * *}$} & \multirow{4}{*}{$\begin{array}{c}0.552 \\
(0.547)\end{array}$} \\
\hline & Attitude & 0.228 & 0.081 & $4.562 * * *$ & & \\
\hline & Subjective norm & 0.433 & 0.083 & $8.473^{* * *}$ & & \\
\hline & PBC & 0.281 & 0.072 & $6.340^{* * *}$ & & \\
\hline \multirow{5}{*}{2} & (Constant) & & 0.066 & $47.903 * * *$ & \multirow{5}{*}{$82.776^{* * *}$} & \multirow{5}{*}{$\begin{array}{c}0.556 \\
(0.550)\end{array}$} \\
\hline & Attitude & 0.227 & 0.081 & $4.547^{* * *}$ & & \\
\hline & Subjective norm & 0.465 & 0.089 & $8.473^{* * *}$ & & \\
\hline & PBC & 0.295 & 0.073 & $6.545^{* * *}$ & & \\
\hline & Team identification & -0.075 & 0.077 & -1.571 & & \\
\hline \multirow{9}{*}{3} & (Constant) & & 0.074 & $42.791 * * *$ & \multirow{9}{*}{$47.262^{* * *}$} & \multirow{9}{*}{$\begin{array}{c}0.559 \\
(0.547)\end{array}$} \\
\hline & Attitude & 0.226 & 0.083 & $4.429 * * *$ & & \\
\hline & Subjective norm & 0.478 & 0.091 & $8.481^{* * *}$ & & \\
\hline & PBC & 0.304 & 0.076 & $6.465 * * *$ & & \\
\hline & Team identification & -0.084 & 0.079 & -1.717 & & \\
\hline & Attitude $\times$ TI & 0.018 & 0.087 & 0.355 & & \\
\hline & $\begin{array}{c}\text { Subjective norm } \times \\
\text { TI }\end{array}$ & -0.054 & 0.085 & -0.967 & & \\
\hline & $\mathrm{PBC} \times \mathrm{TI}$ & 0.051 & 0.077 & 1.073 & & \\
\hline & \multicolumn{4}{|c|}{ Durbin Watson $=2.012$} & & \\
\hline
\end{tabular}

Dependent variable: Sport event attendance intention, TI: Team identification. ${ }^{* * *} p<0.001$.

\section{Discussion and Conclusions}

This study aimed to generate a theoretical research model using the TPB framework to explain the complicated psychological process of professional sports fans' decision formation for attending sports matches at stadiums amid the SARS-CoV-2 pandemic. These findings revealed intricate associations among the research variables, but a significant moderating role of team identification was not identified in the model. Based on the results, the present study provided several theoretical and practical implications.

\subsection{Theoretical Implications}

While recognizing the relationship between attitude and sport event attendance intention, this study considered the arguments of existing studies in various fields, which suggested that attitude contributed to improving the sport event attendance intention. 
For example, applying the TPB, Guo, Berkshire, Fulton, and Hermanson [34] explored a theoretical model to predict the intention to use evidence-based management among U.S. healthcare administrators. They confirmed that the intention could be predicted statistically by their attitudes at the significance level of $<0.001$. Park, Hsieh, and Lee [55] tested a structural equation model using the extended TPB to explain Chinese college students' intention to travel to Japan. Structural analyses indicated that attitude had the greatest impact on intention. A study in sports marketing conducted by Ha [56] examined the relationships among team identification, attitude importance to a sports team, resistance to change, and intention to attend future games to a collegiate basketball team among U.S. students. Ha [56] reported that attitude was a determinant of intention. Therefore, to enhance the intention to attend sports matches, team managers or marketers need to make efforts to reduce the sports fans' negative attitudes toward attending a sports match, which could result in a positive attitude.

Unlike previous studies that applied TPB, the current study showed that subjective norm was the most influential factor in predicting sport event attendance intention ( $\beta=0.513, p<0.001)$. According to Ajzen [23], it was widely acknowledged that the subjective norm was the weakest predictor of the behavioral intentions in various behavioral domains, which was aligned with a recent study. For example, merging two theories, the norm activation model and TPB, Kim and Hwang [57] explored the antecedents of the eco-friendly behavioral intention in the context of drone food delivery services. They reported that the subjective norm was the weakest influential factor in forming a behavioral intention $(\beta=0.119 p<0.05)$. In the context of the SARS-CoV-2 pandemic, the present study found that subjective norm had the highest effect size. In other words, this result means that support from family and friends plays the most important role in the decision to attend sport events. Generally, human being are social animals. They need other people to know what they are doing, saying, and thinking, and this applies specifically to sports team managers and marketers, who need to understand better the key relationship between the subjective norm and sport event attendance intention during the SARS-CoV-2 pandemic.

By identifying the positive relationship between $\mathrm{PBC}$ and sport event attendance intention, the result could be applied during the SARS-CoV-2 pandemic. For example, college students could encounter some barriers to attending sports matches when stadiums are open to spectators, such as a lack of substantial recent information about the state of SARS$\mathrm{CoV}-2$, insufficient money due to declining household income, and a college's recommendation that prevents them from multi-use facilities. These barriers may negatively influence the sport event attendance intention of sports fans. In the current study, PBC is a critical determinant. The result of this study is consistent with previous studies. For example, a recent tourism study conducted by Soliman [58] proposed an extended TPB model and found that PBC played a key role in improving the intention to revisit. Chen and Tung [59] developed an extended TPB research model, inclusive of environmental concerns and perceived morals, and suggested that PBC contributed to a higher propensity to revisit green hotels. Hence, sports team marketers should not overlook the importance of PBC in building sport event

attendance intention.

Finally, the moderating effects of team identification on the relationships among the 'attitude and sport event attendance intention', 'subjective norm and sport event attendance intention', and 'PBC and sport event attendance intention' were not found to be significant in the study, which was different to the authors' expectations. This result can be explained. First, the characteristics of the sample in the present study were different from those in existing studies. The research data were collected from undergraduate and graduate students who were sports fans, while other existing researchers collected data from various age groups $[44,46]$. Furthermore, South Koreans generally have lower attachments to professional sports teams based on local areas than do people in other countries [60]. The reason is that Koreans tend to have a low regional identity because they frequently move to other parts of the country to attend a good high school or university, enter a good company, 
or create business opportunities [61,62]. Moreover, traditionally, professional sports teams in South Korea that rely heavily on financial support from their parent companies have focused primarily on promoting the corporate image and marketing products instead of attracting sports fans [63]. Recently, as many parent companies have reduced their financial support, an increasing number of sports team marketers are making much more effort to develop effective marketing strategies to make profits [46]. Marketers should not minimize the importance of team identification because enhancing it would be an effective way to promote ticket sales.

\subsection{Practical Implications}

The key findings of this study have important marketing implications for sports team managers or marketers. In other words, these findings suggest that the managers or marketers are encouraged to make unremitting efforts to reduce sports fans' risk perception regarding SARS-CoV-2 and enhance their intention to attend sports matches. In particular, sports team managers must strive hard to relieve sports fans' anxiety about becoming infected with the virus in the stadium. For example, there can be some league quarantine guidelines, such as disinfecting the entire stadium, undergoing temperature checks, filling out a digital entry log with a QR code, wearing a face mask during matches, sitting apart in the stands, prohibiting spectators from bringing in food or beverages other than water, banning vocal cheering, and opening all gates in the stadium. Above all, sports teams need to promote their quarantine efforts to sports fans. Indeed, no mass infections have been reported in South Korea's stadiums because of these efforts. If sports fans perceive that attending sports matches at the stadiums will not lead to infection, they are more likely to consider performing the behavior positively. Similarly, sports team employees and athletes are required to follow quarantine guidelines, such as banning private gatherings of five, communicating with colleagues by e-mail, checking social distancing guidelines of the government frequently, telecommuting a few days a week, ventilating indoor spaces frequently, and washing hands with soap for at least $20 \mathrm{~s}$. If one employee or athlete becomes infected, the team must be shut down for two weeks. Hence, employees and athletes must follow quarantine rules.

\subsection{Limitations and Future Study Directions}

Despite the meaningful findings of the current study, there were some limitations. First, according to the TPB, although behavioral intention is likely to lead to actual behavior, this study did not examine this relationship because stadiums in South Korea are currently not fully open to spectators. In future research, it would be interesting to include actual behavior in the TPB when the stadiums are almost open. Second, the behavioral beliefs influencing attitude in the TPB were not investigated. Therefore, the antecedents of attitude toward attending sports matches need to be explored to broaden the understanding of attitude. Third, while the proposed model was based on the TPB, the explanatory power of the model was not sufficient to capture the sports fans' intention entirely. Hence, the applicability of the model of goal-directed behavior, which has been developed to overcome the limitations of TPB, should be tested. Fourth, the proposed model included team identification as a moderating variable, but it did not moderate the paths in the model. Accordingly, future research should examine other meaningful moderating variables (e.g., risk aversion, sports team involvement, and demographic variables). Fifth, because new variants of SARS-CoV-2 have emerged in the U.K. and South Africa, the crisis may continue for an extended time. In future research, it would be worth investigating the impact of perceived risk of a virus on the proposed model. As perceived risk has a negative influence on consumer intention, the concept has an important part in understanding psychology and behavior of consumers [64]. Finally, because the sample of this study was limited to undergraduate and graduate students, future studies should survey various age groups. 
Author Contributions: Conceptualization, Y.J.; methodology, Y.J.; software, Y.J.; validation, S.-K.K.; formal analysis, Y.J.; investigation, S.-K.K.; resources, Y.J.; data curation, S.-K.K.; writing-original draft preparation, Y.J.; writing—review and editing, S.-K.K.; visualization, J.-G.Y.; supervision, J.-G.Y.; project administration, J.-G.Y.; funding acquisition, J.-G.Y. All authors have read and agreed to the published version of the manuscript.

Funding: This research received no external funding.

Institutional Review Board Statement: Not applicable.

Informed Consent Statement: Informed consent was obtained from all subjects involved in the study.

Conflicts of Interest: The authors declare no conflict of interest.

\section{References}

1. Liu, Y.-C.; Kuo, R.-L.; Shih, S.-R. COVID-19: The first documented coronavirus pandemic in history. Biomed. J. 2020 , 43, 328-333. [CrossRef] [PubMed]

2. Park, N.R. Total cumulative 110.7 Million People Decreased by 10,690 People from the Day before New Infected People, News Free Zone, 3 March, 2021. Available online: http:/ / www.newsfreezone.co.kr/news/articleView.html?idxno=302607/ (accessed on 8 March 2021).

3. Linnane, C. 117 Million and U.S. Death Toll Tops 525,000, MarketWatch, 8 March, 2021 . Available online: https: / / www.marketwatch.com/story/coronavirus-tally-global-cases-of-covid-19-near-117-million-and-us-death-toll-tops-52 5000-2021-03-08 (accessed on 8 March 2021).

4. Lee, H.S. Seoul Announces New, 5-Tier Social Distancing system, Korea Biomedical Review, 22 November, 2020. Available online: https: / / www.koreabiomed.com/news/articleView.html?idxno=9529 (accessed on 23 November 2020).

5. Ock, H.J.S. Korea to Maintain Least Strict Social Distancing Rules Next Week, The Korea Herald, 6 November 2020. Available online: http: / / www.koreaherald.com/view.php?ud=20201106000174 (accessed on 23 November 2020).

6. Bichker, L. Coronavirus: How South Korea is Teaching Empty Classrooms, BBC, 9 April 2020. Available online: https://www. bbc.com/news/world-asia-52230371 (accessed on 23 November 2020).

7. Polyzos, S.; Samitas, A.; Spyridou, A.E. Tourism demand and the COVID-19 pandemic: An LSTM approach. Tour. Recreat. Res. 2020, 22, 1-13.

8. Saunders, P. COVID-19 Pandemic's Effect on Sports Could Be Long Lasting, The Denver Post, 30 December 2020. Available online: https://www.denverpost.com/2020/12/30/pandemic-effect-sports-long-lasting/ (accessed on 31 December 2020).

9. Yoo, J.H. Pro Football League to Reopen Stadium Gats Friday, Yonhap, 12, October 2020. Available online: https://en.yna.co.kr/ view / AEN20201012007100315 (accessed on 25 November 2020).

10. Madden, M. Sports Consumers Dwindling during Pandemic, TRIB, 18 November 2020. Available online: https:/ triblive.com/ sports / mark-madden-sports-consumers-dwindling-during-pandemic/ (accessed on 23 November 2020).

11. Ajzen, I.; Madden, T.J. Prediction of goal-directed behavior: Attitudes, intentions, and perceived behavioral control. J. Exp. Soc. Psychol. 1986, 22, 453-474. [CrossRef]

12. Bosnjak, M.; Ajzen, I.; Schmidt, P. The theory of planned behavior: Selected recent advances and applications. Eur. J. Psychol. 2020, 16, 352-356. [CrossRef] [PubMed]

13. Fishbein, M.; Ajzen, I. Belief, Attitude, Intention, and Behavior: An Introduction to Theory and Research; Addison-Wesley: Boston, MA, USA, 1977.

14. Kim, M.S.; James, J. The theory of planned behaviour and intention of purchase sport team licensed merchandise. Sport Bus. Manag. Int. J. 2016, 6, 228-243. [CrossRef]

15. Eddosary, M.; Sagas, M.; Ko, Y.J.; Kim, H.Y. Consumers' Intention to Attend Soccer Events: Application and Extension of the Theory of Planned Behavior. Psychol. Rep. 2015, 117, 89-102. [CrossRef]

16. Potwarka, L.R. Exploring Physical Activity Intention as a Response to the Vancouver Olympics: An Application and Extension of the Theory of Planned Behavior. Event Manag. 2015, 19, 73-92. [CrossRef]

17. Santos, M. An Attendance Behavior Model At Sports Events: Comparison and Constrast of Two Models. Sport Sci. Rev. 2012, 21, 21-42. [CrossRef]

18. Kaplanidou, K.; Gibson, H.J. Predicting Behavioral Intentions of Active Event Sport Tourists: The Case of a Small-scale Recurring Sports Event. J. Sport Tour. 2010, 15, 163-179. [CrossRef]

19. Trail, G.T.; Anderson, D.F.; Fink, J.S. Consumer satisfaction and identity theory: A model of sport spectator conative loyalty. Sport Mark. Q. 2005, 14, 98-111.

20. Ham-Gi, N.K.; Mangan, J.A. Ideology, politics, power: Korean sport-transformation, 1945-92. Int. J. Hist. Sport 2002, 19, $213-242$.

21. Kim, B.-C. Professional Baseball in Korea: Origins, Causes, Consequences and Implications. Int. J. Hist. Sport 2008, 25, 370-385. [CrossRef]

22. Kim, S.; Yoo, E.; Pedersen, P.M. Market segmentation in the K-League: An analysis of spectators of the Korean Professional Soccer League. Int. J. Sports Mark. Spons. 2007, 8, 26-43. [CrossRef] 
23. Ajzen, I. The theory of planned behavior. Organ. Behav. Hum. Decis. Process. 1991, 50, 179-211. [CrossRef]

24. Doll, J.; Ajzen, I. Accessibility and stability of predictors in the theory of planned behavior. J. Personal. Soc. Psychol. 1992, 63, 754-765. [CrossRef]

25. Untaru, E.-N.; Ispas, A.; Candrea, A.N.; Luca, M.; Epuran, G. Predictors of individuals' intention to conserve water in a lodging context: The application of an extended Theory of Reasoned Action. Int. J. Hosp. Manag. 2016, 59, 50-59. [CrossRef]

26. Fishbein, M.; Ajzen, I. Predicting and Changing Behavior: The Reasoned Action Approach; Psychological Press: New York, NY, USA, 2009.

27. Kim, S.; Lee, J.; Yoon, D. Norms in Social Media: The Application of Theory of Reasoned Action and Personal Norms in Predicting Interactions With Facebook Page Like Ads. Commun. Res. Rep. 2015, 32, 322-331. [CrossRef]

28. Kim, E.; Chung, K.-S.; Chepyator-Thomson, J.R.; Lu, Z.; Zhang, J.J. The LPGA's global tour and domestic audience: Factors influencing viewer's intention to watch in the United States. Sport Soc. 2020, 23, 1793-1810. [CrossRef]

29. De Groot, J.; Steg, L. General Beliefs and the Theory of Planned Behavior: The Role of Environmental Concerns in the TPB. J. Appl. Soc. Psychol. 2007, 37, 1817-1836. [CrossRef]

30. Azjen, I. Understanding Attitudes and Predicting Social Behavior; Prentice Hall: Englewood Cliffs, NJ, USA, 1980.

31. Ajzen, I. The theory of planned behavior: Frequently asked questions. Hum. Behav. Emerg. Technol. 2020, 2, 314-324. [CrossRef]

32. Madden, T.J.; Ellen, P.S.; Ajzen, I. A comparison of the theory of planned behavior and the theory of reasoned action. Pers. Soc. Psychol. Bull. 1992, 18, 3-9. [CrossRef]

33. Han, H.; Meng, B.; Kim, W. Emerging bicycle tourism and the theory of planned behavior. J. Sustain. Tour. 2017, 25, 292-309. [CrossRef]

34. Guo, R.; Berkshire, S.D.; Fulton, L.V.; Hermanson, P.M. Predicting intention to use evidence-based management among U.S. healthcare administrators: Application of the theory of planned behavior and structural equation modeling. Int. J. Heal. Manag. 2017, 12, 25-32. [CrossRef]

35. Lee, Y.-J.; Won, D.; Bang, H. Why do event volunteers return? Theory of planned behavior. Int. Rev. Public Nonprofit Mark. 2014, 11, 229-241. [CrossRef]

36. Shin, Y.H.; Im, J.; Jung, S.E.; Severt, K. The theory of planned behavior and the norm activation model approach to consumer behavior regarding organic menus. Int. J. Hosp. Manag. 2018, 69, 21-29. [CrossRef]

37. Vesci, M.; Botti, A. Festival quality, theory of planned behavior and revisiting intention: Evidence from local and small Italian culinary festivals. J. Hosp. Tour. Manag. 2019, 38, 5-15. [CrossRef]

38. Reysen, S.; Chadborn, D.; Plante, C.N. Theory of planned behavior and intention to attend a fan convention. J. Conv. Event Tour. 2018, 19, 204-218. [CrossRef]

39. Cunningham, G.B.; Kwon, H. The Theory of Planned Behaviour and Intentions to Attend a Sport Event. Sport Manag. Rev. 2003, 6, 127-145. [CrossRef]

40. Chiu, W.S.; Bae, J.S.; Won, D.Y. The role of sport fan ethnocentrism in viewing intention of the Major League Baseball: An application of the Theory of Planned Behavior. Korean. J. Sport Manag. 2015, 20, 29-43.

41. Lee, H.-S. Examining neighborhood influences on leisure-time walking in older Korean adults using an extended theory of planned behavior. Landsc. Urban Plan. 2016, 148, 51-60. [CrossRef]

42. Zhang, Y. Exploring factors influencing the viewing intention of E-sports competitions in China: An application of the extended theory of planned behavior and online social capital. Korean J. Advert. 2020, 31, 33-62. [CrossRef]

43. Suh, Y.I.; Ahn, T.; Pedersen, P.M. Examining the effects of team identification, e-service quality (e-SQ) and satisfaction on intention to revisit sports websites. Int. J. Sports Mark. Spons. 2013, 14, 2-19. [CrossRef]

44. Theodorakis, N.D.; Koustelios, A.; Robinson, L.; Barlas, A. Moderating role of team identification on the relationship between service quality and repurchase intentions among spectators of professional sports. Manag. Serv. Qual. Int. J. 2009, 19, 456-473. [CrossRef]

45. Lee, H.W.; Gipson, C.; Barnhill, C. Experience of spectator flow and perceived stadium atmosphere: Moderating role of team identification. Sport Mark. Q. 2017, 26, 87-98.

46. Jeong, Y.-D. The role of motivation, involvement, and experience in forming team loyalty of professional soccer supporters. Korean J. Sport Manag. 2019, 24, 1-18. [CrossRef]

47. Han, H.; Hsu, L.T.J.; Sheu, C. Application of the theory of planned behavior to green hotel choice: Testing the effect of environmental friendly activities. Tour. Manag. 2010, 31, 325-334. [CrossRef]

48. Ajzen, I. Constructing a Theory of Planned Behavior Questionnaire. 2010. Available online: http://people.umass.edu/aizen/ pdf/tpb.measurement.pdf (accessed on 15 November 2020).

49. Perugini, M.; Bagozzi, R.P. The role of desires and anticipated emotions in goal-directed behaviours: Broadening and deepening the theory of planned behaviour. Br. J. Soc. Psychol. 2001, 40, 79-98. [CrossRef]

50. Shapiro, S.L.; Reams, L.; So, K.K.F. Is it worth the price? The role of perceived financial risk, identification, and perceived value in purchasing pay-per-view broadcasts of combat sports. Sport Manag. Rev. 2019, 22, 235-246. [CrossRef]

51. Hooper, D.; Coughlan, J.; Mullen, M.R. Structural equation modelling: Guidelines for determining model fit. Elec. J. Bus. Res. Meth. 2008, 6, 53-60.

52. Hair, J.F.; Black, W.C.; Babin, B.J.; Anderson, R.E. Multivariate Data Analysis, 7th ed.; Pearson: Upper Saddle River, NJ, USA, 2010. 
53. Fornell, C.; Larcker, D.F. Evaluating structural equation models with unobservable variables and measurement error. J. Market. Res. 1981, 18, 39-50. [CrossRef]

54. Tabachnick, B.G.; Fidell, L.S. Experimental Designs Using ANOVA; Duxbury Press: Belmont, CA, USA, 2007.

55. Park, S.H.; Hsieh, C.-M.; Lee, C.-K. Examining Chinese College Students' Intention to Travel to Japan Using the Extended Theory of Planned Behavior: Testing Destination Image and the Mediating Role of Travel Constraints. J. Travel Tour. Mark. 2017, 34, 113-131. [CrossRef]

56. Ha, J.H. An examination of the relationships among team identification, attitude importance, resistance to change, and intention to attend future games to a collegiate basketball team. Korean Soc. of Spo. Manage. 2010, 15, 15-27.

57. Kim, J.J.; Hwang, J. Merging the norm activation model and the theory of planned behavior in the context of drone food de-livery services: Does the level of product knowledge really matter? J. Hosp. Tour. Manag. 2020, 42, 1-11. [CrossRef]

58. Soliman, M. Extending the Theory of Planned Behavior to Predict Tourism Destination Revisit Intention. Int. J. Hosp. Tour. Adm. 2019, 1-26. [CrossRef]

59. Chen, M.-F.; Tung, P.-J. Developing an extended Theory of Planned Behavior model to predict consumers' intention to visit green hotels. Int. J. Hosp. Manag. 2014, 36, 221-230. [CrossRef]

60. Kim, S.W.; Lim, K.T. An analysis of relationship between sports involvement, regional identity and professional baseball by region. Korean. J. Sport 2019, 17, 355-364. [CrossRef]

61. Kang, E.T.; Ma, K.R. A study on the factors affecting student migration to higher education in the Seoul metropolitan area. Korean Plan. Assoc. 2014, 49, 5-16. [CrossRef]

62. Park, S.H.; Kim, K.M.; Lee, K.S. Prediction for the spatial distribution of jobs for the youth and the elderly in the Seoul met-ropolitan area. Korean. Geogr. Soc. 2018, 53, 75-89.

63. Jeong, Y.; Kim, E.; Kim, M.; Zhang, J.J. Exploring relationships among organizational culture, empowerment, and organiza-tional citizenship behavior in the South Korean professional sport industry. Sustainability 2019, 11, 5412. [CrossRef]

64. Ariffin, S.K.; Mohan, T.; Goh, Y.N. Influence of consumers' perceived risk on consumers' online purchase intention. J. Res. Inter. Market. 2018, 12, 309-327. 